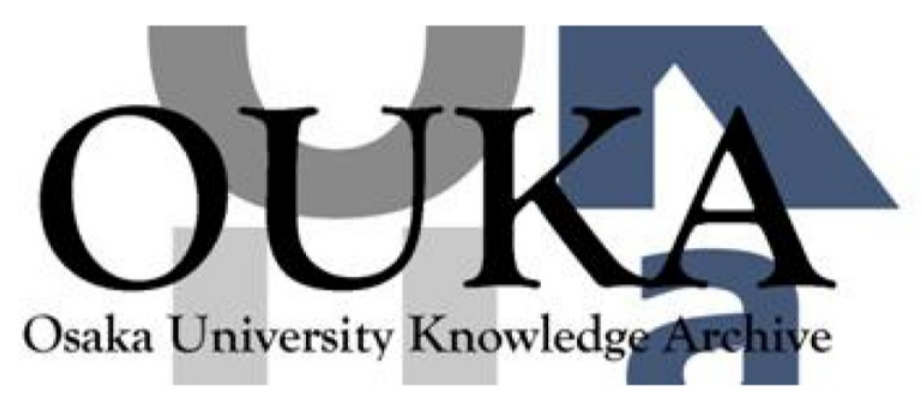

\begin{tabular}{|c|l|}
\hline Title & $\begin{array}{l}\text { Measurement of Critical Shear Stress for } \\
\text { Erosion of Cohesive Riverbanks }\end{array}$ \\
\hline Author(s) & $\begin{array}{l}\text { Bui, Trong Vinh; Deguchi, Ichiro; Arita, Mamoru } \\
\text { et al. }\end{array}$ \\
\hline Citation & $\begin{array}{l}\text { Annual Report of FY 2007, The Core University } \\
\text { Program between Japan Society for the Promotion } \\
\text { of Science (JSPS) and Vietnamese Academy of } \\
\text { Science and Technology (VAST). p. 206-p. 218 }\end{array}$ \\
\hline Issue Date & 2008 \\
\hline oaire:version VoR \\
\hline URL & https://hdl. handle. net/11094/13036 \\
\hline rights & \\
\hline Note & \\
\hline
\end{tabular}

Osaka University Knowledge Archive : OUKA

https://ir. Library. osaka-u. ac. jp/

Osaka University 


\title{
Measurement of Critical Shear Stress for Erosion of Cohesive Riverbanks
}

Bui Trong Vinh*, Ichiro Deguchi*, Mamoru Arita*, Susumu Araki*

* Department of Civil Engineering, Osaka University, Suita, 565-0871, Japan

\begin{abstract}
Riverbank erosion near river mouth is an increasingly serious problem for social-economic and environment. There are many factors impact on erosion process such as bank materials, mangrove trees, animal burrows, meteorological conditions and hydrodynamics. In this paper, the authors investigated the critical shear stress for erosion of cohesive riverbanks in Soai Rap River, southern Viet Nam. Initial results showed that the riverbanks have been moderately eroded with the critical shear stress ranged from 0 to $5.731 \mathrm{~N} / \mathrm{m}^{2}$ and the erodibility coefficient ranged from 0.497 to 9.07 $\mathrm{cm}^{3} / \mathrm{N}$-s. Simultaneously, the environmental conditions effect on critical shear stress were also explained.
\end{abstract}

KEY WORDS: cohesive riverbanks, critical shear stress, riverbank erosion, Soai Rap River.

\section{INTRODUCTION}

Soai Rap River is one of the most important rivers in southern part of VietNam. It is the largest outfall of the Dong Nai and Sai Gon river system with $660 \mathrm{~m}$ wide at the narrowest section and $3000 \mathrm{~m}$ at the widest one. The depth at the river's widest section is about $6-7 \mathrm{~m}$. The riverbanks of the Soai Rap River have been eroded severely in some positions by hydrodynamic action such as wind waves, ship waves and tidal flows.

In recent years, because of social - economic developing demand, the government of Ho Chi Minh City planned to dredge Soai Rap River to more than 13 meters for large ships $(20.000-50.000$ DWT) moving to Saigon Port and many deep ports can be built along the banks of the Soai Rap River. Wave generated by ships navigating the river may cause bank erosion. In addition, many residents constructed shrimp ponds along the riverbanks. These development will accelerate bank erosion. Our final object is to predict the possibility of the bank erosion in Soai Rap riverbanks.

Determining the critical shear stress for erosion is the crucial work to calculate the erosion rates of riverbanks. To measure the critical shear stress of the Soai Rap riverbanks, the authors selected six actively eroding banks for detailed study. The study is approximately located between $106^{\circ} 43^{\prime}$ to $106^{\circ} 53^{\prime}$ in longitude and $10^{\circ} 21^{\prime}$ to $10^{\circ} 21^{\prime}$ in latitude (Fig.1). 


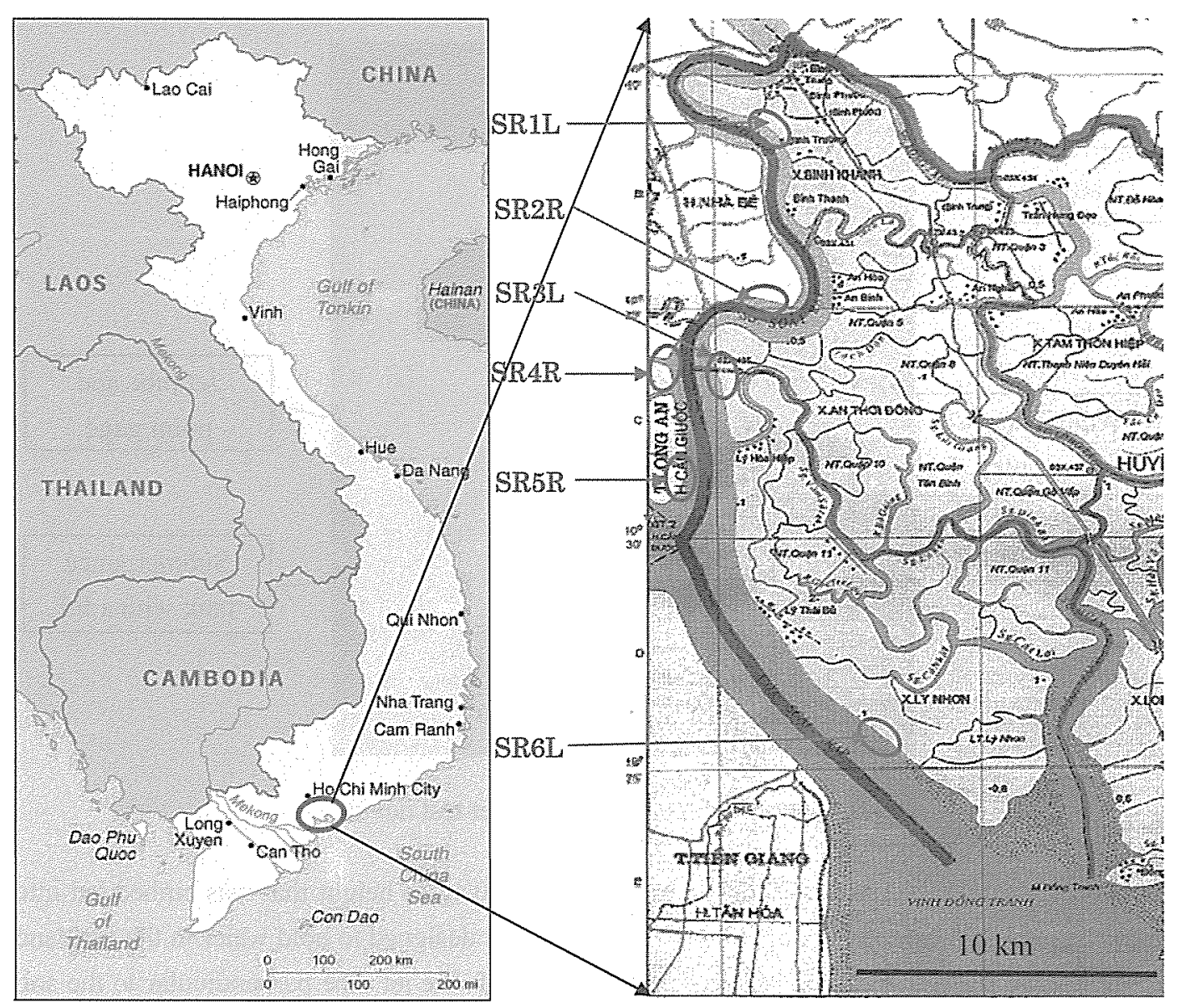

Fig 1. Study area and measuring sites in the Soai Rap riverbanks

\section{METHODS}

\section{Apparatus of Jet Testing}

To measure the critical shear stress of riverbanks for the erosion by fluid motion, a non-vertical submerged jet test device was used. This device was developed based on some previous researchers (Hanson and Kook, 2002). The non-vertical jest test device consists of a pump, adjustable head tank, jet submergence tank, a point gage, and other support materials (Fig.2) 


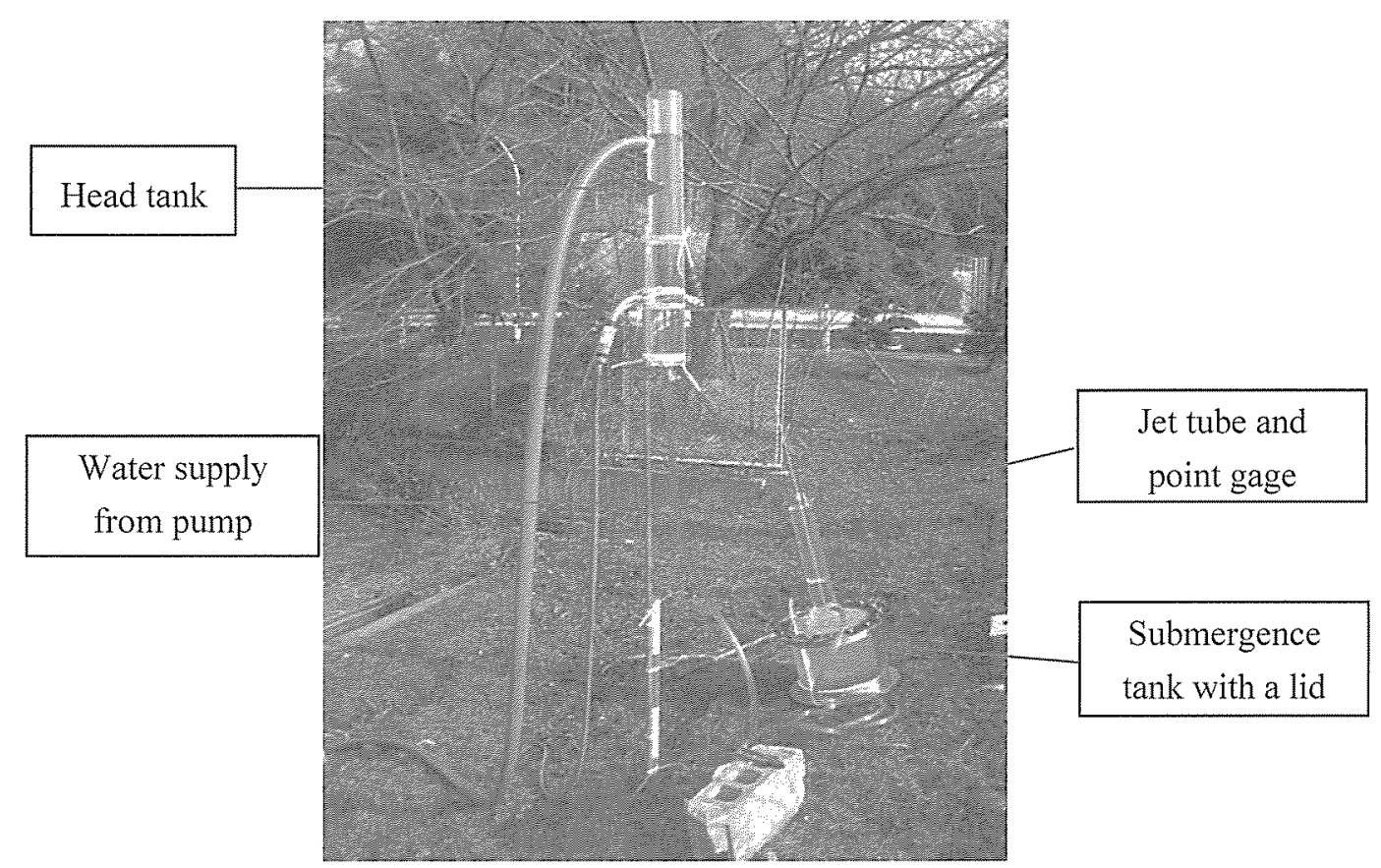

Fig 2. Non-vertical submerged jet test device

The jet submergence tank is about $30 \mathrm{~cm}$ in diameter and $30 \mathrm{~cm}$ in height that was embedded into the soil to a depth of $20 \mathrm{~cm}$. The lid of submergence tank was designed to hold water in the tank and opened to measure the scour depth. Besides, the lid also holds the jet tube perpendicular to the soil surface and holds the discharge tube and pressure gage.

The jet tube is designed to allow a point gage to pass through the orifice, shutting off flow, and to take soil surface measurements as scour occurs during testing.

The head tank was used to control the hydraulic shear stress and to dampen fluctuations in pumping level. The water was pumped from and discharged to the Soai Rap River.

\section{Operating Principles}

The non-vertical submerged jet test device is operated based on the diffusion principles of a submerged circular jet, and scour beneath an impinging jet (Hanson and Cook, 2002). Fig.3 described the detail of the diffusion principles where $\mathrm{d}_{0}$ is the orifice diameter $(0.006 \mathrm{~m}), \mathrm{J}_{\mathrm{e}}$ is the equilibrium depth ( $\mathrm{m}$ ), $\mathrm{J}_{\mathrm{i}}$ is the initial jet orifice height $\left(\mathrm{m}\right.$ ), and $\mathrm{J}_{\mathrm{p}}$ is the potential core length (about $0.037 \mathrm{~m})$. 


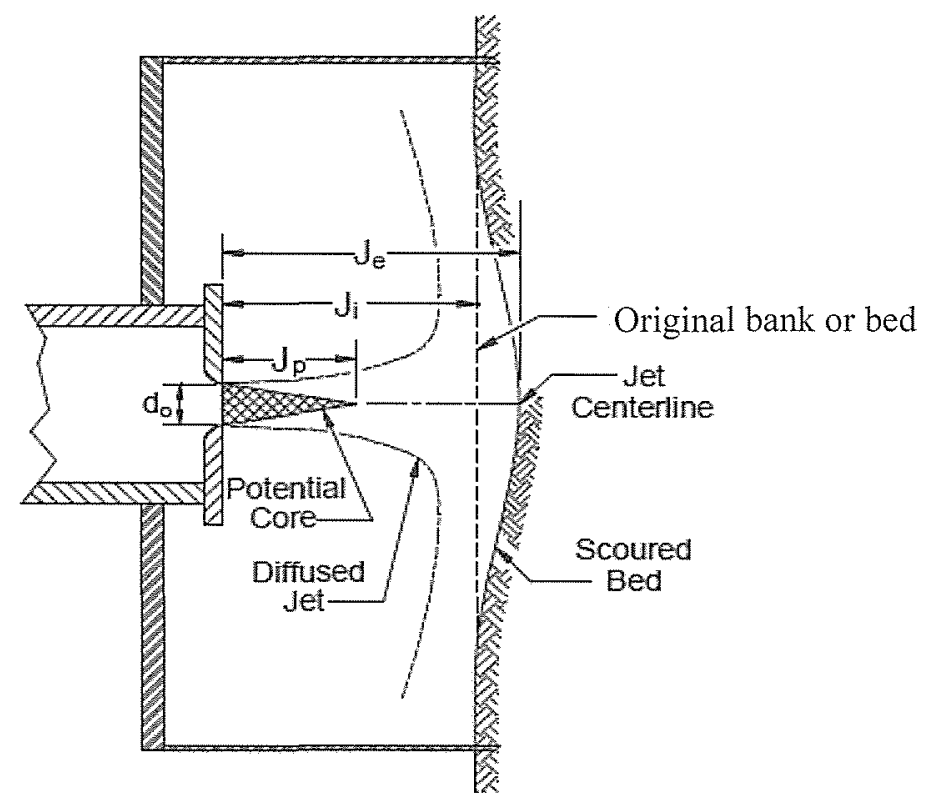

Fig. 3. Operating principles of the non-vertical submerged jet test device

When the rate of change in the depth of scour diminishes to zero, equilibrium depth $\mathrm{J}_{\mathrm{e}}$ is attained and critical shear stress is calculated by Eq. 1 (Hanson and Cook, 2002):

$$
\tau_{c}=\tau_{0} *\left(\frac{J_{p}}{J_{e}}\right)^{2}
$$

where $\tau_{0}$ is the maximum stress due to the jet velocity at the orifice $\mathrm{U}_{0}(\mathrm{~m} / \mathrm{s})$ and calculated by Eq. 2:

$$
\tau_{0}=C_{f} * \rho * U_{0}^{2}
$$

where $C_{\mathrm{f}}$ is the friction coefficient $(0.00416), \rho$ is the density of river water $\left(1010 \sim 1025 \mathrm{~kg} / \mathrm{m}^{3}\right), U_{0}$ is determined by the authors in Eq. 3:

$$
U_{0}=0.046 * H^{0.4899}
$$

where $H$ is the differential head. The relationship between the initial velocity of water jet $U_{0}(\mathrm{~m} / \mathrm{s})$ and the measured differential head $\mathrm{H}(\mathrm{m})$ was calibrated by the authors as shown in Fig. 4. 


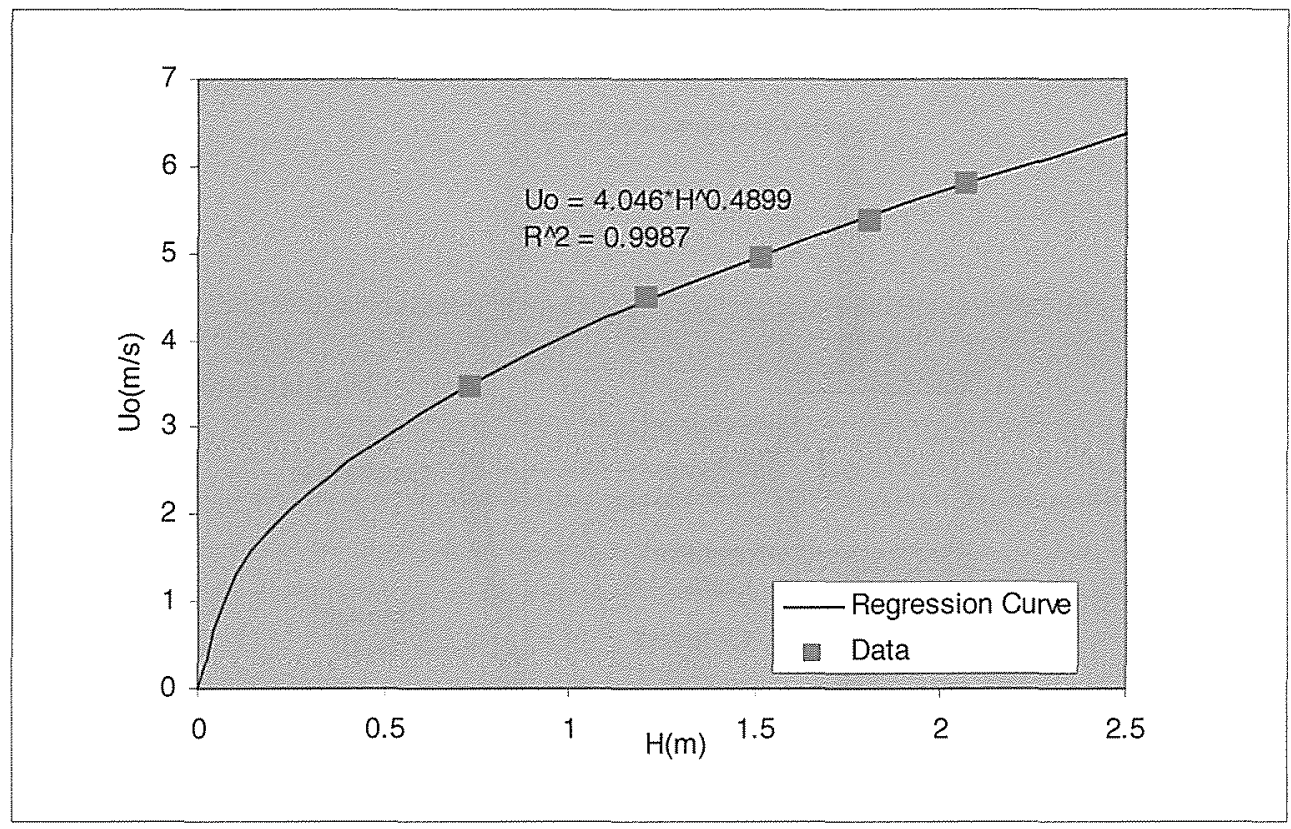

Fig. 4. Calibration of the initial jet velocity at orifice

\section{Analytical Methods}

The critical shear stress is determined based on equilibrium scour depth $\mathrm{J}_{\mathrm{e}}$ (Eq.1). The difficulty of determining equilibrium scour depth is that the length of time required to reach equilibrium can be very large (Hanson and Cook, 2002). Field data will be recorded in spreadsheet estimates the equilibrium depth using the scour depth versus time and the hyperbolic function. The general form of the equation can be computed by Eq. 4 :

$$
\left(f-f_{0}\right)^{2}-x^{2}=A^{2}
$$

where $A$ is the value for the semi-transverse and semi-conjugate axis of the hyperbola; $f, f_{0}$ and $x$ are calculated by Eq. 5, Eq.6, and Eq.7, respectively.

$$
\begin{aligned}
& f=\log \left(\frac{J}{d_{0}}\right)-\log \left(\frac{H_{0} * t}{d_{0}}\right) \\
& f_{0}=\log \left(\frac{J_{e}}{d_{0}}\right) \\
& x=\log \left(\frac{U_{0} * t}{d_{0}}\right)
\end{aligned}
$$


where $t$ is the time of data reading. The spreadsheet routine determines the minimum standard error for the Eq. 4 versus the jet test data.

The erodibility coefficient $k_{d}$ is determined based on the scour depth, time, pre-determined $\tau_{c}$ and the dimensionless time function as described by Eq. 8 .

$$
t=T_{r}\left[\frac{1}{2} \ln \left(\frac{1+J_{i}^{*}}{1-J_{i}^{*}}\right)-J^{*}-\frac{1}{2} \ln \left(\frac{1+J_{p}^{*}}{1-J_{p}^{*}}\right)+J_{p}^{*}\right]
$$

where the dimensionless terms are defined as $\mathrm{J}_{\mathrm{i}}{ }^{*}=\mathrm{J}_{\mathrm{i}} / \mathrm{J}_{\mathrm{e}}$, and $\mathrm{J}_{\mathrm{p}}{ }^{*}=\mathrm{J}_{\mathrm{p}} / \mathrm{J}_{\mathrm{e}}, \mathrm{t}$ is measured time, $\mathrm{T}_{\mathrm{r}}=$ $\mathrm{J}_{\mathrm{e}} /\left(\mathrm{k}_{\mathrm{d}} * \tau_{\mathrm{c}}\right)$ is a reference time.

On the other hand, ASTM methods were also used to analyze the physical properties of the riverbank materials.

\section{ENVIRONMENTAL CONDITIONS}

\section{Temperature}

The study area is in the tropical climate region and has two distinct seasons, the dry season and the rainy season. The rainy season lasts from May to November and the dry season from December to April. The average temperature is around $28^{\circ} \mathrm{C}$ as in Fig. 5. In April, the highest temperature on average is about $30^{\circ} \mathrm{C}$. From December to January, the lowest temperature on average is about $26^{\circ} \mathrm{C}$. These temperatures cause the desiccation process of the riverbanks.

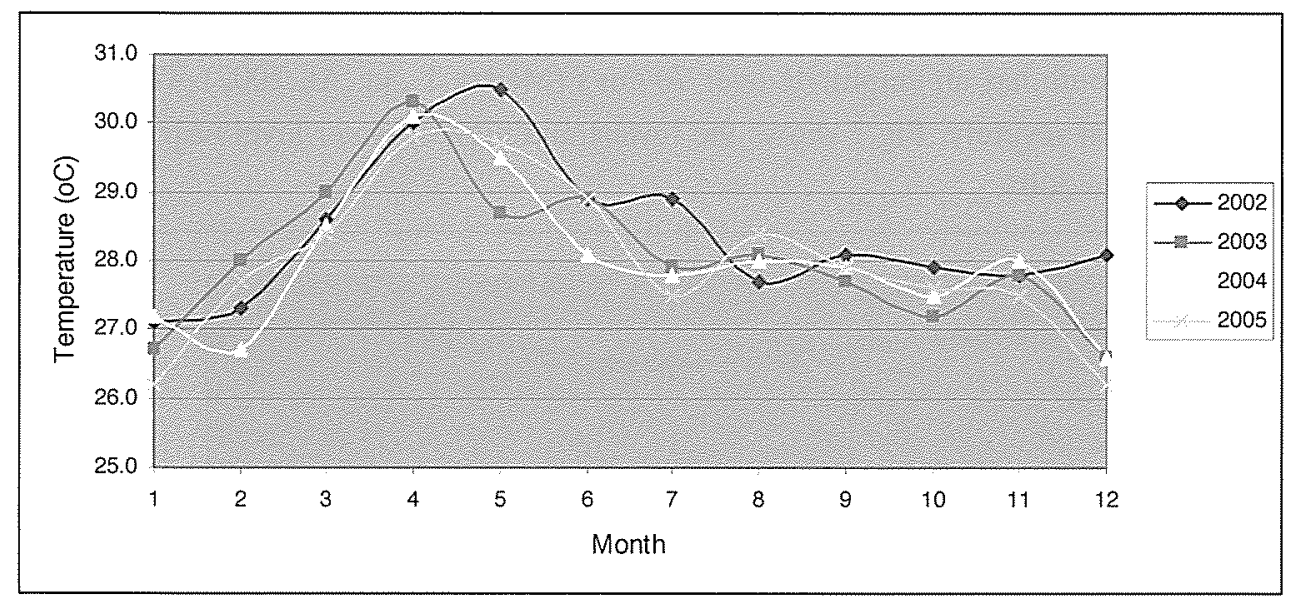

Fig. 5. Average air temperature from 2002 to 2005 (Tan Son Hoa Station) 


\section{Rainfall}

In the study area, the rainfall is quite high averaging $1949 \mathrm{~mm}$ a year. Ninety percent of the rainfall is in the rainy season from May to November, and the highest rainfall is in June and September (Fig. 6). The rainfall can be the reason to increase the erosion of cohesive riverbank soils.

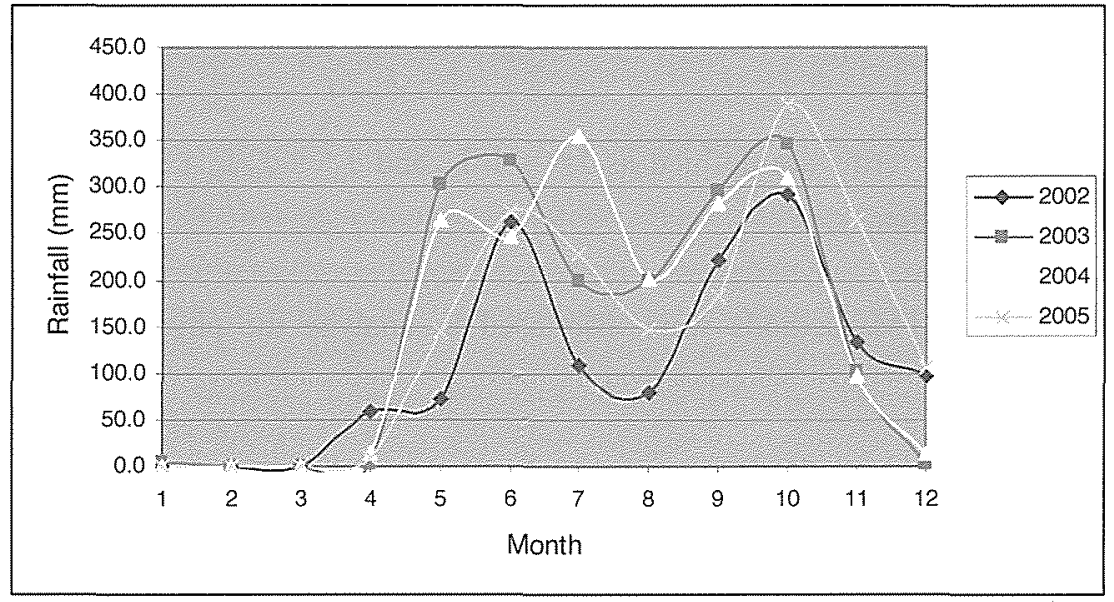

Fig. 6. Annual rainfall from 2002 to 2005 (Tan Son Hoa Station)

\section{Tidal level}

The study area has an irregular semi-diurnal tidal regime with high amplitude $(3.3-4.1 \mathrm{~m})$ in the spring tide and low amplitude $(0.3 \mathrm{~m}-2.2 \mathrm{~m})$ in the neap tide. The high and low amplitude of tidal level together with river flow form strong currents in Soai Rap River. The tidal currents near the Soai Rap river mouth has an amplitude over $70 \mathrm{~cm} / \mathrm{s}$ (Madza T., et. Al, 2002). These currents will cause bank erosion severely. Fig. 7 shows the lowest and highest water level near study sites in the years from 2002 to 2005 .

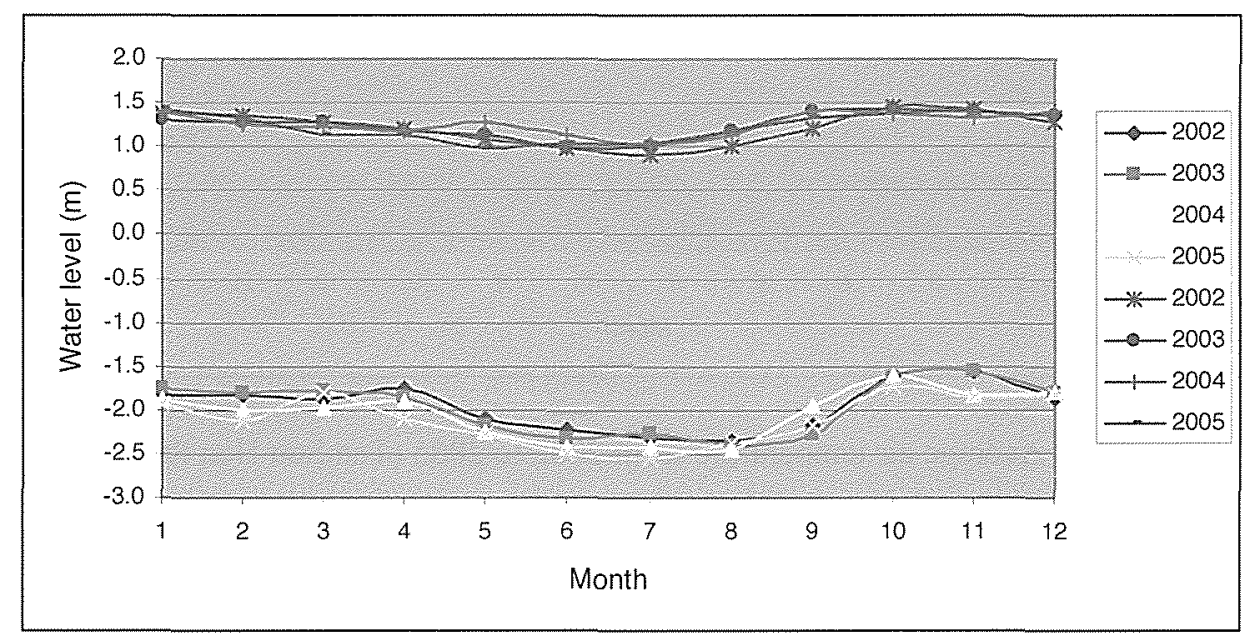

Fig. 7. The shallowest and highest water level from 2002 to 2005 (Phu An Station) 


\section{Waves}

Wind waves and ship waves are also main causes to erode the riverbank materials. The wind wave height is usually high in the spring tide and in the northeast moonsoon (from October to March). The wave field data in the study sites have not been measured. The wave field and current field need to be measured and modeled to determine the excess shear stress on the banks.

\section{Vegetation and Animal}

Along the riverbanks, mangrove tree fringes are dominated. The species of mangrove trees change from Avicennia, Rhizophora and Nypa Palm. These mangrove trees usually protect land from erosion. However, in the study sites, many mangrove trees have been collapsed because of hydraulic forces (waves, currents) and exposed shallow roots to the environments.

On the other hand, there are various aquatic animals such as crabs, shells, fish etc. which burrow and make many holes in the riverbanks. These holes will cause the mangrove trees unstable to waves and currents. Figs. 8 9 show the actions of waves and currents and shallow exposed roots of mangroves with many burrowed holes.

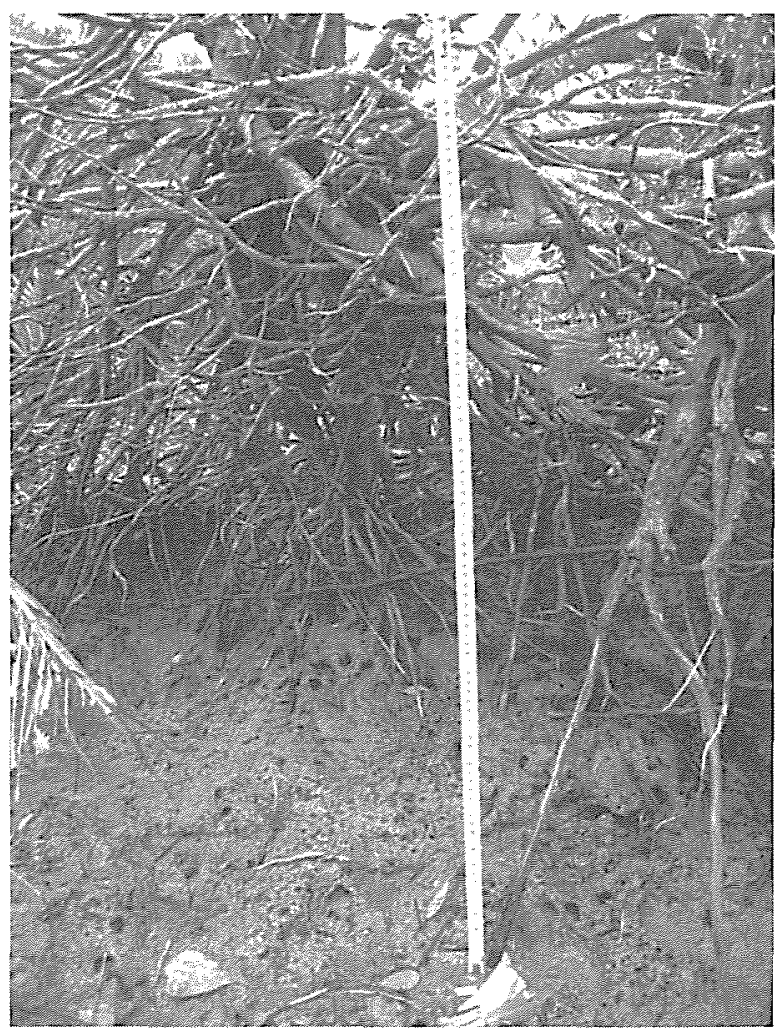

Fig. 8. Exposed roots of mangroves and burrowed holes 


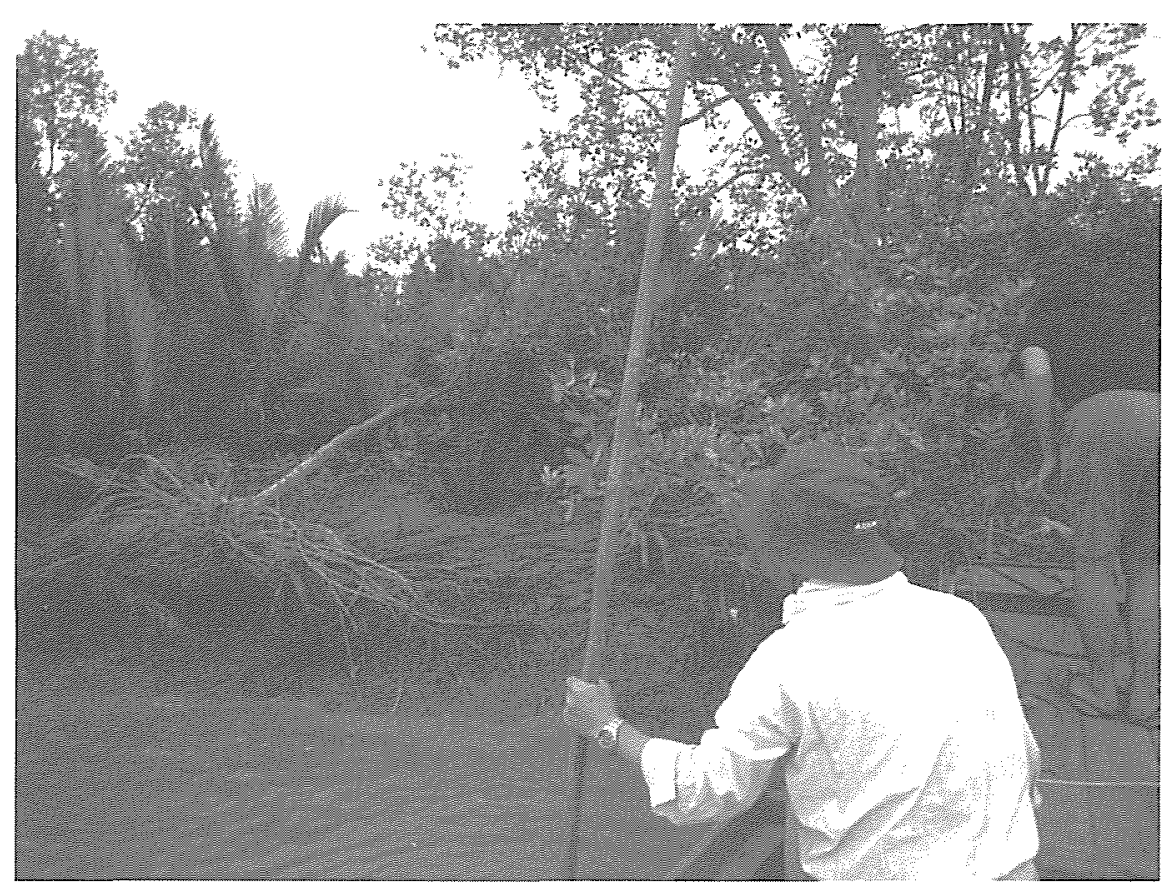

Fig. 9. Mangrove trees were collapsed at measuring site SR5R

\section{RESULTS AND DISCUSSION}

Because most riverbanks near river mouth are inundated tides in the spring tide, the measurements were carried out during the neap tide from $6^{\text {th }}-8^{\text {th }}$ March 2007 which tidal level ranged from $1.7 \mathrm{~m}$ to $2.2 \mathrm{~m}$ as in Table 1 .

Table 1 . Tidal level in the study site

\begin{tabular}{|c|c|c|c|c|c|c|c|c|}
\hline \multirow{2}{*}{ DATE } & \multicolumn{2}{|c|}{ Spring tide } & \multicolumn{2}{c|}{ Spring tide } & \multicolumn{2}{c|}{ Neap tide } & \multicolumn{2}{c|}{ Neap tide } \\
\cline { 2 - 9 } & Hours & $\mathrm{m}$ & Hours & $\mathrm{m}$ & Hours & $\mathrm{m}$ & Hours & $\mathrm{m}$ \\
\hline $03 / 06 / 2007$ & $18: 28$ & 3.6 & $05: 30$ & 3.5 & $00: 19$ & 2.1 & $12: 25$ & 1.7 \\
\hline $03 / 07 / 2007$ & $18: 27$ & 3.5 & $06: 07$ & 3.4 & $00: 52$ & 2.0 & $12: 56$ & 2.0 \\
\hline $03 / 08 / 2007$ & $18: 32$ & 3.5 & $06: 48$ & 3.3 & $13: 25$ & 2.2 & $01: 25$ & 1.9 \\
\hline
\end{tabular}

In the site of SRIL, the authors could not measure the critical shear stress because of very soft soil with high clay content and unconsolidated material.

The scour rate of site SR2R changed from $3.4 \mathrm{~cm}$ at first 5 minutes and $3.6 \mathrm{~cm}$ at the second 5 minutes and $4.2 \mathrm{~cm}$ at the last 5 minutes. The scour rate data were fitted with the hyperbolic form as Eq. 4 and described in Fig. 10. 


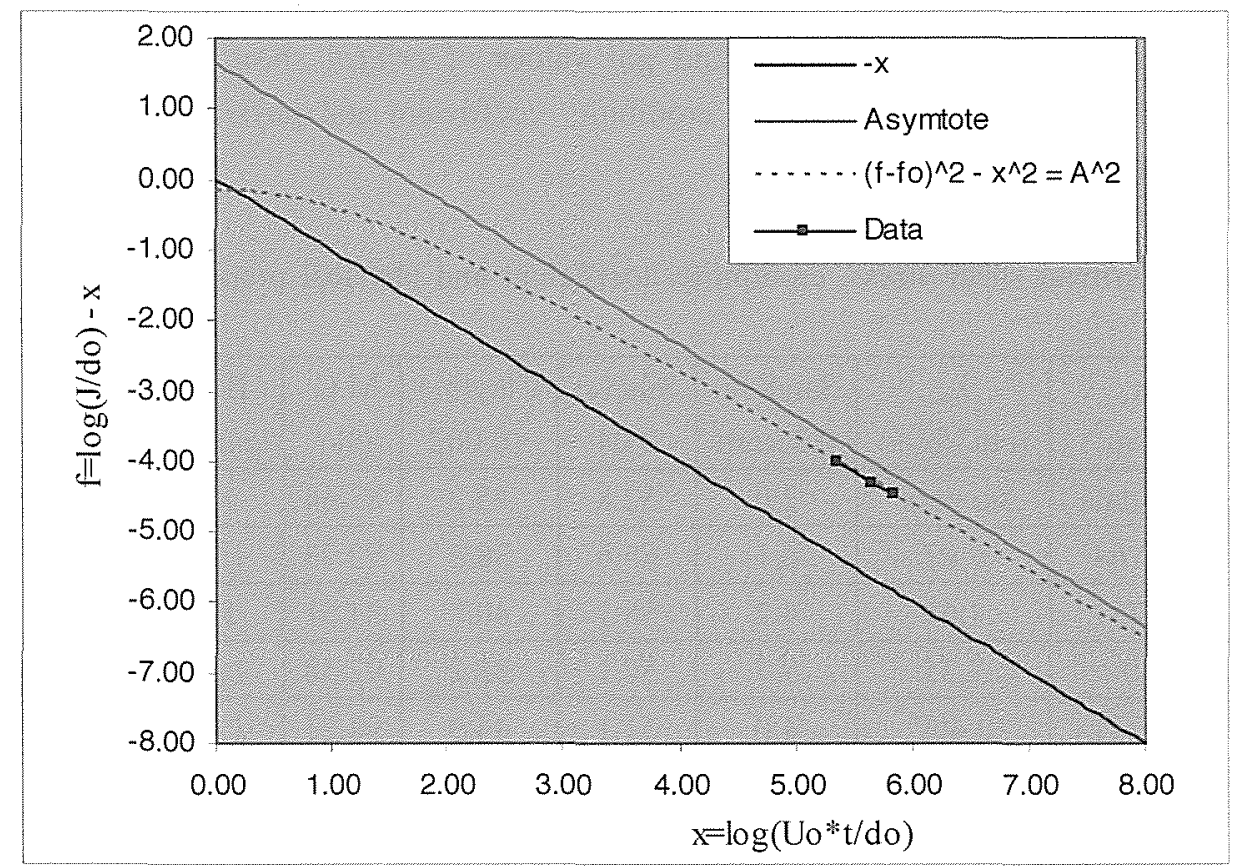

Fig.10. Fit of scour rate data at SR2R to determine $\tau_{\mathrm{c}}$

From Eq.1, the critical shear stress was easily calculated and got $1.764 \mathrm{~N} / \mathrm{m}^{2}$. The erodibility coefficient was determined by Eq. 8. Fig. 11 shows the curve fits the measure jet data to Eq. 8. From this routine the erodibility coefficient of measuring site SR2R was $9.07 \mathrm{~cm}^{3} / \mathrm{N}$-s.

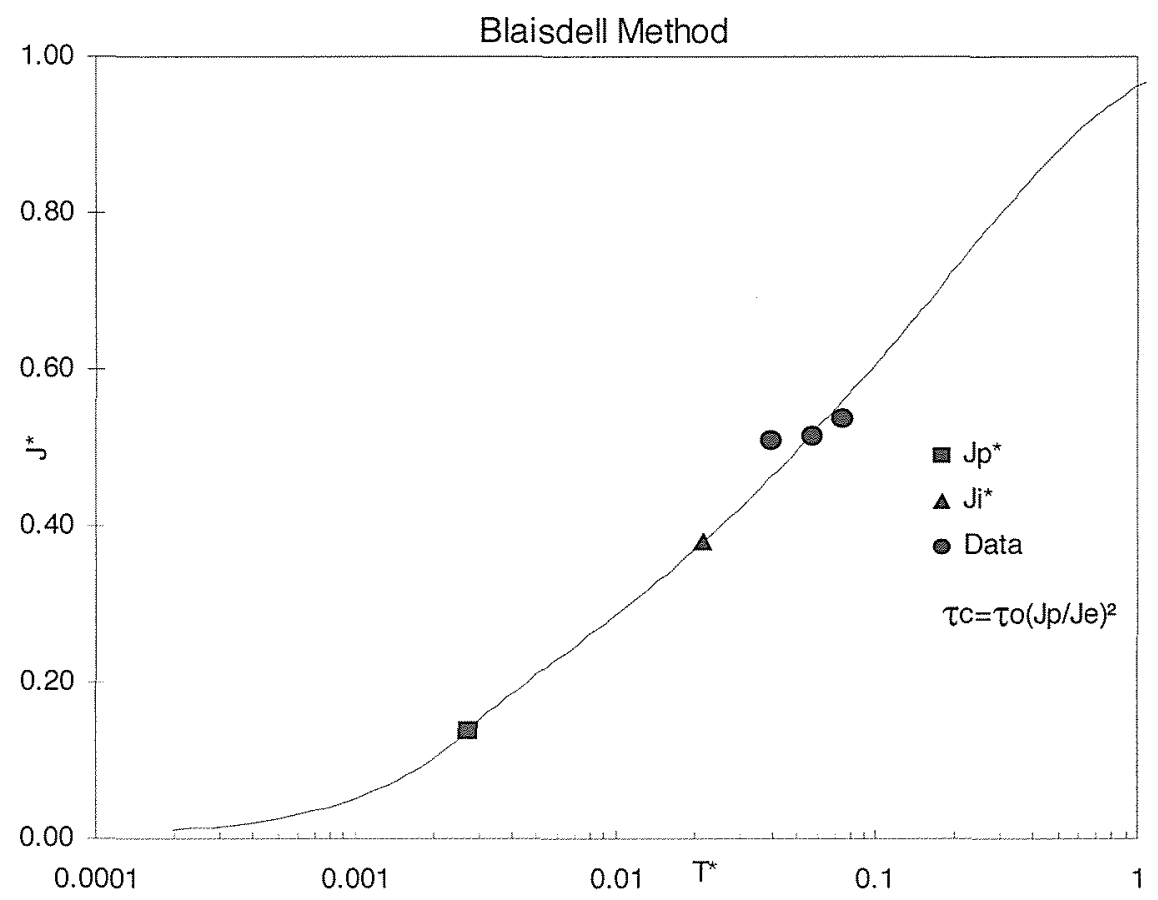

Fig. 11. Fit of scour rate data at SR2R to determine $\mathrm{k}_{\mathrm{d}}$ 
From the scour rate data of four remain measuring sites (SR3L, SR4R, SR5R, SR6L), authors also fitted the data to the hyperbolic form and got values of critical shear stress and erodibility coefficient. The critical shear stress, the erodibility coefficient and physical properties of bank materials are shown in Table 2.

Table 2. The critical shear stress, erodibility coefficient and physical properties of the Soai Rap riverbanks

\begin{tabular}{|c|c|c|c|c|c|c|c|c|c|}
\hline $\begin{array}{c}\text { Sample } \\
\text { No }\end{array}$ & $\begin{array}{c}\tau_{\mathrm{c}} \\
\left(\mathrm{N} / \mathrm{m}^{2}\right)\end{array}$ & $\begin{array}{c}\mathrm{k}_{\mathrm{d}} \\
(\mathrm{cm} 3 / \mathrm{N}-\mathrm{s})\end{array}$ & $\begin{array}{c}\text { Sand(\%) } \\
0.25 \mathrm{~mm}\end{array}$ & $\begin{array}{c}\text { Silt(\%) } \\
0.04\end{array}$ & $\begin{array}{c}\text { Clay(\%) } \\
<0.002\end{array}$ & $\begin{array}{c}\text { M.C. } \\
(\%)\end{array}$ & $\begin{array}{c}\text { B.D. } \\
\mathrm{g} / \mathrm{cm}^{3}\end{array}$ & $\begin{array}{c}\text { S.G } \\
\mathrm{g} / \mathrm{cm}^{3}\end{array}$ & $\begin{array}{c}\text { P.I } \\
(\%)\end{array}$ \\
\hline SR1L & no data & no data & 2.0 & 52.8 & 45.2 & 83.64 & 1.5 & 2.63 & 33.52 \\
\hline SR2R & 1.764 & 9.07 & 6.1 & 55.6 & 38.3 & 92.73 & 1.47 & 2.64 & 34.92 \\
\hline SR3L & 5.731 & 4.61 & 4.2 & 55.1 & 40.7 & 84.51 & 1.5 & 2.64 & 38.15 \\
\hline SR4R & 0 & 2.35 & 9.7 & 57.1 & 33.2 & 92.58 & 1.47 & 2.63 & 40.08 \\
\hline SR5R & 4.271 & 0.497 & 4.0 & 51.1 & 44.9 & 98.21 & 1.45 & 2.62 & 42.32 \\
\hline SR6L & 0.171 & 0.745 & 19.4 & 48.7 & 31.9 & 73.89 & 1.55 & 2.65 & 36.35 \\
\hline
\end{tabular}

SR1L, SR3L,SR6L: sampling and measuring sites of the left bank.

SR2R, SR4R,5R: sampling and measuring sites of the right bank.

M.C.: Moisture Content; B.D.: Bulk Density; S.G: Specific Gravity; P.I: Plasticity Index;

From the results shown in Table 2, the authors found that the relationship between critical shear stress and sand content is quite clear. It seems to be that when the sand content of bank materials increases, the critical shear stress will decrease as illustrated in Fig. 12.

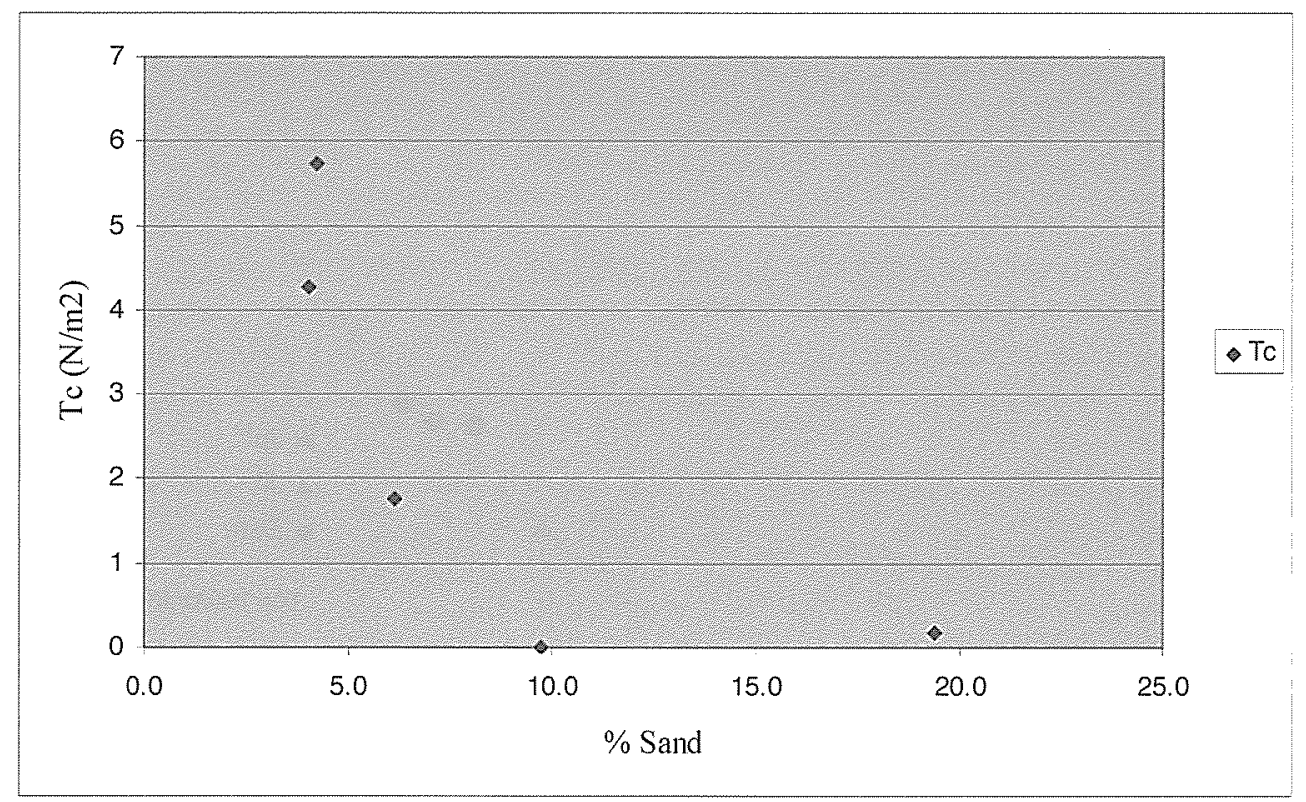

Fig. 12. The critical shear stress versus the sand content 
The relationship between critical shear stress and the erodibility coefficient is showed in Fig. 13.

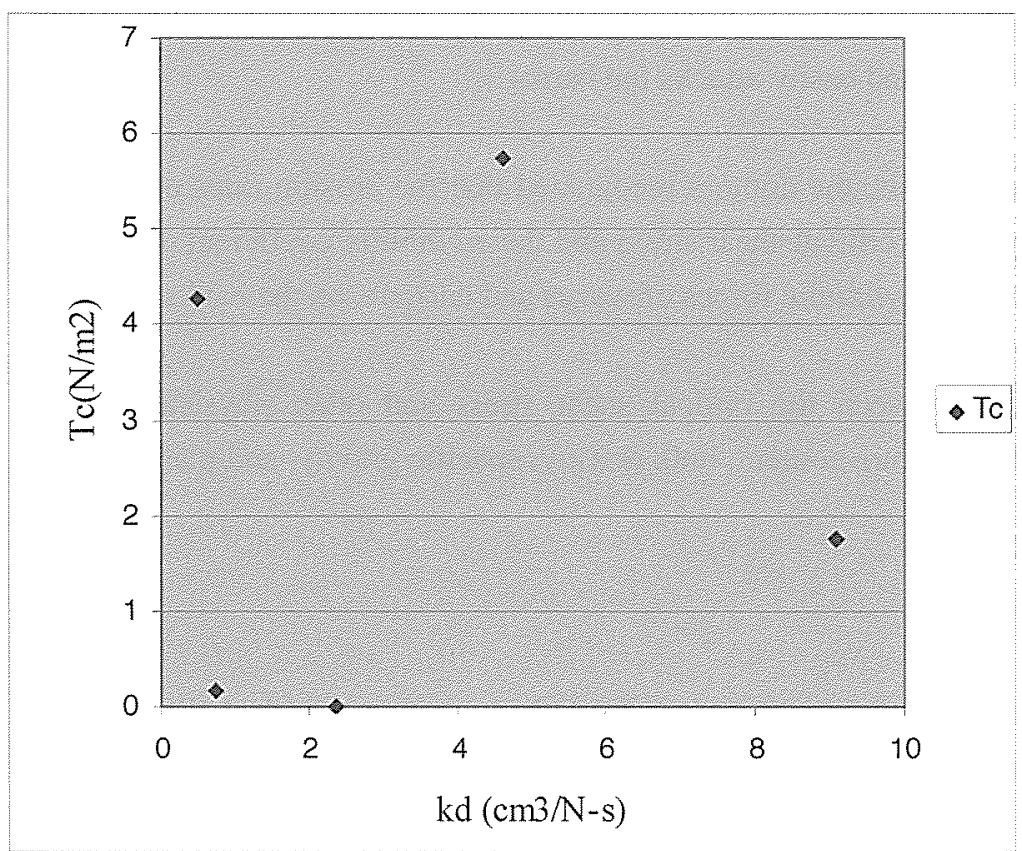

Fig. 13. The critical shear stress versus the erodibility coefficients

From Fig. 13, it is very difficult to find the clear relationship between the critical shear stress and the erodibilty coefficient. This means that when the critical shear stress decreases, the erodibility coefficient can increase or decrease.

At measuring site SR2R, the critical shear stress is quite low $\left(1.764 \mathrm{~N} / \mathrm{m}^{2}\right)$ and the erodibility coeffcient is high $\left(9.07 \mathrm{~cm}^{3} / \mathrm{N}-\mathrm{s}\right)$. It is agreement with the authors's observations in the field because the measuring site SR2R has eroded quite severely.

At the measuring sites SR3L, the critical shear stress and the erodibility coefficient are quite high $\left(\tau_{\mathrm{c}}=5.731 \mathrm{~N} / \mathrm{m}^{2}, \mathrm{k}_{\mathrm{d}}=4.61 \mathrm{~cm}^{3} / \mathrm{N}-\mathrm{s}\right)$. These values showed that the measuring site SR3L has eroded moderately.

At the measuring site SR4R, the critical shear stress got a value of zero. It could be said that this site will be eroded easily when hydrodynamic forces attack.

At the measuring site SR5R, the critical shear stress is quite high $\left(4.271 \mathrm{~N} / \mathrm{m}^{2}\right)$ and the erodibility coeffcient is low $\left(0.497 \mathrm{~cm}^{3} / \mathrm{N}\right.$-s $)$. This means that the site SR5R has been eroded not severly but many mangrove tress have been collapsed. It could be said that the roots and burrow holes accompany with hydodynamic forces are main factors caused bank erosion. 
At the measuring site SR6L, although the critical shear stress is very low $\left(0.171 \mathrm{~N} / \mathrm{m}^{2}\right)$ but the erodibility coefficient is also low $\left(0.745 \mathrm{~cm}^{3} / \mathrm{N}-\mathrm{s}\right)$. These values do not mean that the erosion rate at this site is low. As our observations, many mangove trees have been collapsed. The wave action in this area is quite high and easily attacks the banks.

From the above analysis, the authors recognized that the erosion rates of cohesive riverbanks will depend not only on the critical shear stress and the erodibility coeffcient of the banks but also on the excess shear stress of hydraulic forces of waves and currents on the banks.

The relationships between the critical shear stress and other physical properties of riverbank materials such as moisture content, bulk density, specific gravity, and plasticity index are not clear.

\section{CONCLUSION}

By using the non-vertical jet test device, the authors measured critical shear stress at five of six sites. The first measuring site could not be measured because of the unconsolidated cohesive bank materials. Five remaining sites showed that the critical shear stress of riverbank materials depends clearly on the sand content.

The erosion rates of cohesive riverbanks will be determined when effective shear stress of hydraulic forces is evaluated. This means that more measurements of waves and currents attack the banks need to be carried out.

\section{ACKNOWLEGEMENTS}

The authors would like to express grateful thanks to the Japan Society for the Promotion of Science (JSPS) for the financial support to do the research. The authors also thank Dr. Hanson with his valuable comments and supported materials.

\section{REFERENCES}

Blaisdell FW, Clayton LA, Hebaus GG. 1981. Ultimate dimension of local scour. Journal of Hydraulics Division, American Society of Civil Engineers 107(HY3): 327-337.

Hanson, G. J. and K. R. Cook, 2002. Non-vertical jet testing of cohesive streambank materials. ASAE paper No.022119.

HoChiMinh City People's Committee. Marching toward the East Sea.

Mazda T. et al, 2002. Coastal erosion due to long-term impact on mangrove forests. Kluwer Academic Publishers.

Statistical Office in HoChiMinh City, 2005. Meteorology - Hydrography. 